\title{
STUDY ANALYSIS OF ORAL TUBERCULOSIS LESION IN SOUTH KALIMANTAN, INDONESIA
}

\author{
Maharani Laillyza Apriasari*, Monita Valentine Silalahi**, Isnur Hatta ${ }^{* \star *}$, Juliyatin Putri Utami** \\ *Department of Oral Medicine, Dentistry Faculty, Universitas Lambung Mangkurat, Banjarmasin, Indonesia \\ **Dentistry Faculty, Universitas Lambung Mangkurat, Banjarmasin, Indonesia \\ ***Department of Public Health, Dentistry Faculty, Universitas Lambung Mangkurat, Banjarmasin, Indonesia \\ ***Department of Biomedic, Dentistry Faculty, Universitas Lambung Mangkurat, Banjarmasin, Indonesia \\ Correspondence : Maharani Laillyza Apriasari, Department of Oral Medicine, Dentistry Faculty of Universitas Lambung Mangkurat, \\ jl veteran 128 B Banjarmasin, South Kalimantan, Indonesia \\ Email : $\underline{\text { maharaniroxy@gmail.com }}$
}

Keywords:
Clinical manifestations,
descriptive analyze, Multi-
Drug Resistant, oral
Tuberculosis, systemic
disease

\section{ABSTRACT}

Background: Tuberculosis is an infectious disease which is the second-largest cause of death in the world after HIV / AIDS. Tuberculosis caused by Mycobacterium tuberculosis that usually attacks the lungs but can manifest in the oral mucosa. Clinical manifestations of oral Tuberculosis related to age, sex, duration of treatment, systemic disease, and Multi-Drug Resistant therapy. There is no research on descriptive studies of oral manifestations of tuberculosis patients in South Kalimantan, specifically in Banjarmasin. This study aims to analyze the clinical manifestations of oral Tuberculosis descriptively in South Kalimantan, Indonesia.

Method: This was a descriptive analysis with cross-sectional study design, based on history and clinical oral examination. It was used 30 respondents by purposive sampling method. Data were analyzed by Chi-square $(p<0.05)$.

Results: During treatment, it showed the correlation between xerostomia and systemic disease (diabetes mellitus and HIV/AIDS) are $(p=0.007)$ and a correlation between xerostomia and duration of treatment $(p=0.024)$. The correlation between candidiasis and systemic disease $(p=0.024)$. The correlation between angular cheilitis and age, sex, duration of treatment, systemic disease, and Multi-Drug Resistant therapy $(p>0.05)$. The clinical manifestations of oral Tuberculosis are xerostomia, candidiasis, and angular cheilitis.

Conclusion: The duration of treatment and the systemic diseases are associated with xerostomia and candidiasis in the oral cavity of TB patients.

\section{INTRODUCTION}

Tuberculosis is a contagious disease that is still a global concern. Tuberculosis (TB) is the second-largest cause of death in the world after HIV/AIDS. ${ }^{1}$ The prevalence of the disease is increasing especially in developing countries because it is supported by several factors such as poverty, humid environment, population density, and increasing cases of resistance to antituberculosis drugs. ${ }^{2}$

Indonesia is a country with the secondlargest number of new cases in the world after India.
In 2016 it was estimated that there were 10.4 million new cases of Tuberculosis with 6.2 million cases in men, 3.2 million cases in women, and 1 million cases in children. In 2016, an estimated 1.7 million deaths from Tuberculosis included 0.4 million tuberculosis deaths in people with HIV. The number of deaths from Tuberculosis decreased by $37 \%$ between 2000 and 2016, but Tuberculosis remained the 10th highest cause of death in the world in 2015. ${ }^{3}$

South Kalimantan is a province that has a high prevalence of Tuberculosis, where the 
prevalence is the same as the average prevalence in Indonesia. The prevalence of pulmonary TB in South Kalimantan based on a doctor's diagnosis in 2013 was $0.3 \%$, and in 2018 it increased to $0.4 \%{ }^{4}$

Tuberculosis is an infectious disease caused by Mycobacterium tuberculosis (MTB) which generally attacks the lungs, but in $10-15 \%$ of cases can affect other organs, including the oral cavity. Tuberculosis can manifest in the oral cavity in primary or secondary. It can spread through blood flow and lymphatic tract. The circumstances of individuals with productive age, smoking habits, are in a humid environment and lack of circulation, as well as a lack of knowledge, will increase the risk of a person suffering from Tuberculosis ..$^{5-7}$

Dentists must know orofacial TB lesions and consider them as differential diagnoses of oral lesions to ensure early diagnosis of TB and its treatment. This is very important because there is often a misdiagnosis. ${ }^{8}$ There are no descriptive studies of clinical manifestations of oral Tuberculosis patients in South Kalimantan, specifically in Banjarmasin. Based on the above, it is necessary to conduct a study of descriptive studies of clinical manifestations of oral Tuberculosis that used data on patients treated at Ulin Banjarmasin Hospital. The purpose of this study was to analyze the clinical manifestations of oral Tuberculosis descriptively in South Kalimantan, Indonesia.

\section{METHODS}

This research is an analysis descriptive. It has been approved by ethical clearance from the Ethics Research Committee of Dentistry Faculty of University Lambung Mangkurat, Banjarmasin, South Kalimantan, Indonesia (No. 100/KEPKGFKGULM/EC/XII/2018). The population in this study were all patients (1.353 population) who came for treatment at the Integrated Tuberculosis Clinic at
Ulin Banjarmasin Hospital. The sample in this study took 30 samples. The sampling technique was taken by purposive sampling method according to inclusion and exclusion criteria. The inclusion criteria in this study were tuberculosis patients who needed treatment and tested positive for Tuberculosis with laboratory tests, patients with a minimum of the 6-month length of visit based on medical records, patients with drug resistance (Multi-Drug Resistant) and patients who agree to be respondents (cooperative) and sign informed consent. The exclusion criteria in this study were patients who did not want to be respondents and patients with conscious disorders. Data were collected from January-March 2019. All data were analyzed by chi-square non-parametric test $(p<0,05)$.

\section{RESULT}

Based on the results of research that had been done in RSUD Ulin Banjarmasin obtained sociodemographic characteristics of respondents which include age, sex, duration of treatment, systemic disease, and MDR (Multi-Drug Resistant) status in pulmonary TB disease patients can be seen in table 1.

Table 1. Sociodemographic characteristics of patients

\begin{tabular}{lll}
\hline \multicolumn{1}{c}{ Variable } & $\mathrm{n}$ & $\%$ \\
\hline Age & & \\
$\quad \leq 45$ years & 16 & 53,3 \\
$\quad>45$ years & 14 & 46,7 \\
Gender & & \\
$\quad$ Man & 17 & 56,7 \\
$\quad$ Women & 13 & 43,3 \\
Duration of treatment & & \\
$\quad 6$ month & 16 & 53,3 \\
$\quad>6$ month & 14 & 46,7 \\
Systemic Disease & & \\
$\quad$ Yes & 17 & 56,7 \\
$\quad$ No & 13 & 43,3 \\
MDR & & \\
$\quad$ Yes & 14 & 46,7 \\
$\quad$ No & 16 & 53,3 \\
& & \\
\hline
\end{tabular}


Based on table 1 can be known characteristics of TB patients aged $\leq 45$ years are 16 people $(53.3 \%)$ which are more than the age group $>45$ years which is 14 people $(46.7 \%)$. Based on gender, the number of men is more than women, the number of men is 17 people $(56.7 \%)$, and women are 13 people (43.3\%). TB patients in this study had a longer duration of treatment in 6 months, 16 people (53.3\%) compared to the span of more than 6 months, namely 14 people (46.7\%). Tuberculosis patients accompanied by systemic diseases were 17 people (56.7\%), and patients without systemic disease were 13 people (43.3\%) whereas there were 14 people based on MDR (Multi-Drug Resistant) status (46.7\%) and without MDR, there were 16 people (53.3\%). 17 patients had xerostomia in their oral cavity and 13 patients who did not have manifestations of xerostomia. 14 patients had candidiasis in their oral cavity and 16 patients who did not have candidiasis. 12 patients had angular cheilitis, and there were 18 patients who did not have manifestations of angular cheilitis. Respondents in the study that manifested xerostomia and candidiasis were $13.3 \%$, respondents with manifestations of xerostomia accompanied by angular cheilitis were $16.7 \%$, manifestations of candidiasis and angular cheilitis were $23.3 \%$, and respondents who had all three manifestations in the cavity its mouth is $6.7 \%$.

The results of the data were analyzed using the Chi-Square Test, to determine the relationship of clinical manifestations of the oral cavity with age, sex, duration of treatment, systemic disease, and Multi-Drug Resistant (MDR) status in Tuberculosis patients at RSUD Ulin Banjarmasin. This analysis used by Fisher's exact test with a significance limit $(p<0.05)$.

Table 2 shows that there is a significant correlation between xerostomia that manifests in the oral cavity of Tuberculosis patients in RSUD Ulin Banjarmasin January-March 2019 with the duration of treatment and systemic disease $(p$ $<0.05$ ). Table 3. show that there is a significant correlation between candidiasis that manifests in the oral mucosa of Tuberculosis patients in RSUD Ulin Banjarmasin January-March 2019 with systemic diseases $(p<0.05)$. Based on the table, it is known that there is no significant correlation between candidiasis and age, genders, duration of treatment, and MDR (Multi-Drug Resistant) status in Tuberculosis patients. Based on Table 4. show that there is no significant correlation between angular cheilitis with age, sex, duration of treatment, systemic disease, and MDR status ( $p>0.05)$.

Table 2. Relation between xerostomia and related factors

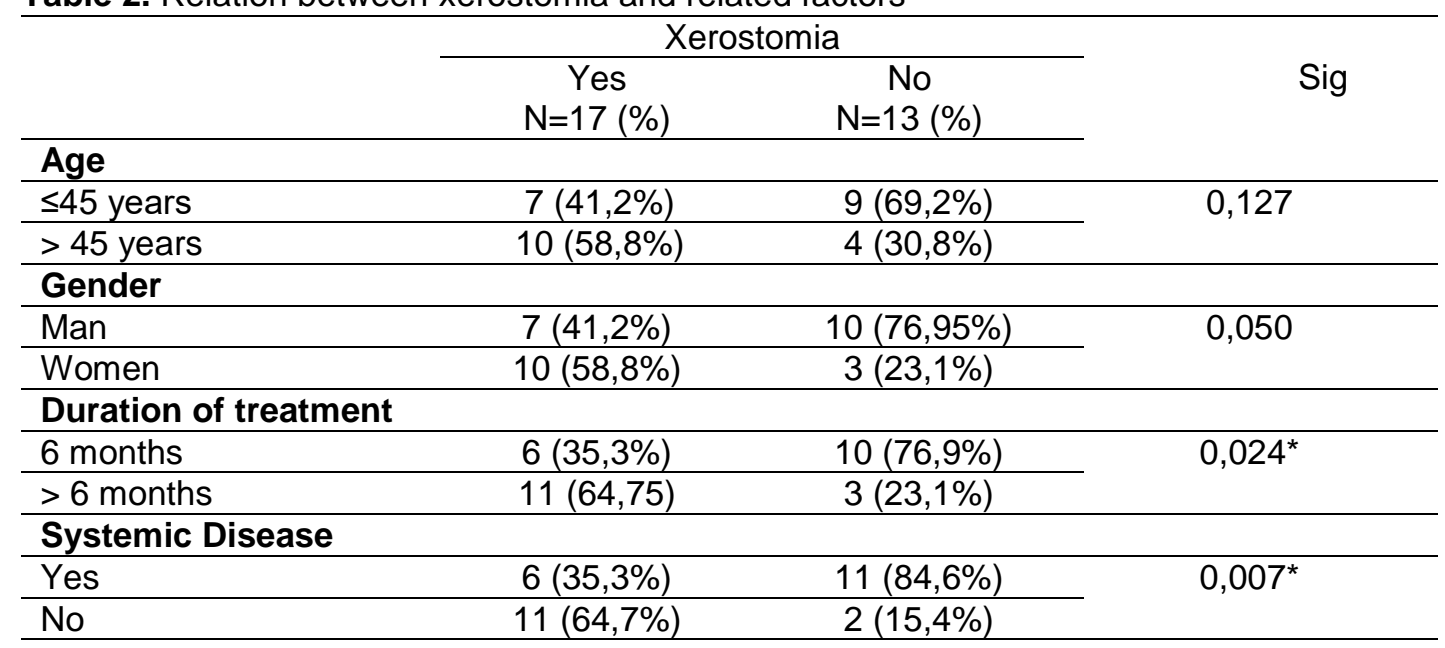




\begin{tabular}{llll}
\hline MDR & & & \\
\hline Yes & $9(52,9 \%)$ & $5(38,5 \%)$ & 0,431 \\
\hline No & $8(47,1 \%)$ & $8(61,5 \%)$ & \\
\hline
\end{tabular}

Table 3. Relation between Candida and related factors

\begin{tabular}{|c|c|c|c|}
\hline & \multicolumn{2}{|c|}{ Candidiasis } & \multirow[b]{2}{*}{ Sig } \\
\hline & $\begin{array}{c}\text { Yes } \\
\mathrm{N}=14\end{array}$ & $\begin{array}{c}\text { No } \\
\mathrm{N}=16\end{array}$ & \\
\hline \multicolumn{4}{|l|}{ Age } \\
\hline$\leq 45$ years & $10(71,4 \%)$ & $6(37,5 \%)$ & \multirow[t]{2}{*}{0,063} \\
\hline$>45$ years & $4(28,6 \%)$ & $10(62,5 \%)$ & \\
\hline \multicolumn{4}{|l|}{ Gender } \\
\hline Man & $8(57,1 \%)$ & $9(56,3 \%)$ & \multirow[t]{2}{*}{0,961} \\
\hline Women & $6(42,9 \%)$ & $7(43,7 \%)$ & \\
\hline \multicolumn{4}{|c|}{ Duration of treatment } \\
\hline 6 months & $10(71,4 \%)$ & $6(37,5 \%)$ & \multirow[t]{2}{*}{0,063} \\
\hline$>6$ months & $4(28,6 \%)$ & $10(62,5 \%)$ & \\
\hline \multicolumn{4}{|c|}{ Systemic Disease } \\
\hline Yes & $11(78,6 \%)$ & $6(37,5 \%)$ & \multirow[t]{2}{*}{$0,024^{*}$} \\
\hline No & $3(21,4 \%)$ & $10(62,5 \%)$ & \\
\hline \multicolumn{4}{|l|}{ MDR } \\
\hline Yes & $6(42,9 \%)$ & $8(50,0 \%)$ & \multirow[t]{2}{*}{0,696} \\
\hline No & $8(57,1 \%)$ & $8(50,0 \%)$ & \\
\hline
\end{tabular}

Table 4. Relation between Angular Cheilitis and related factors

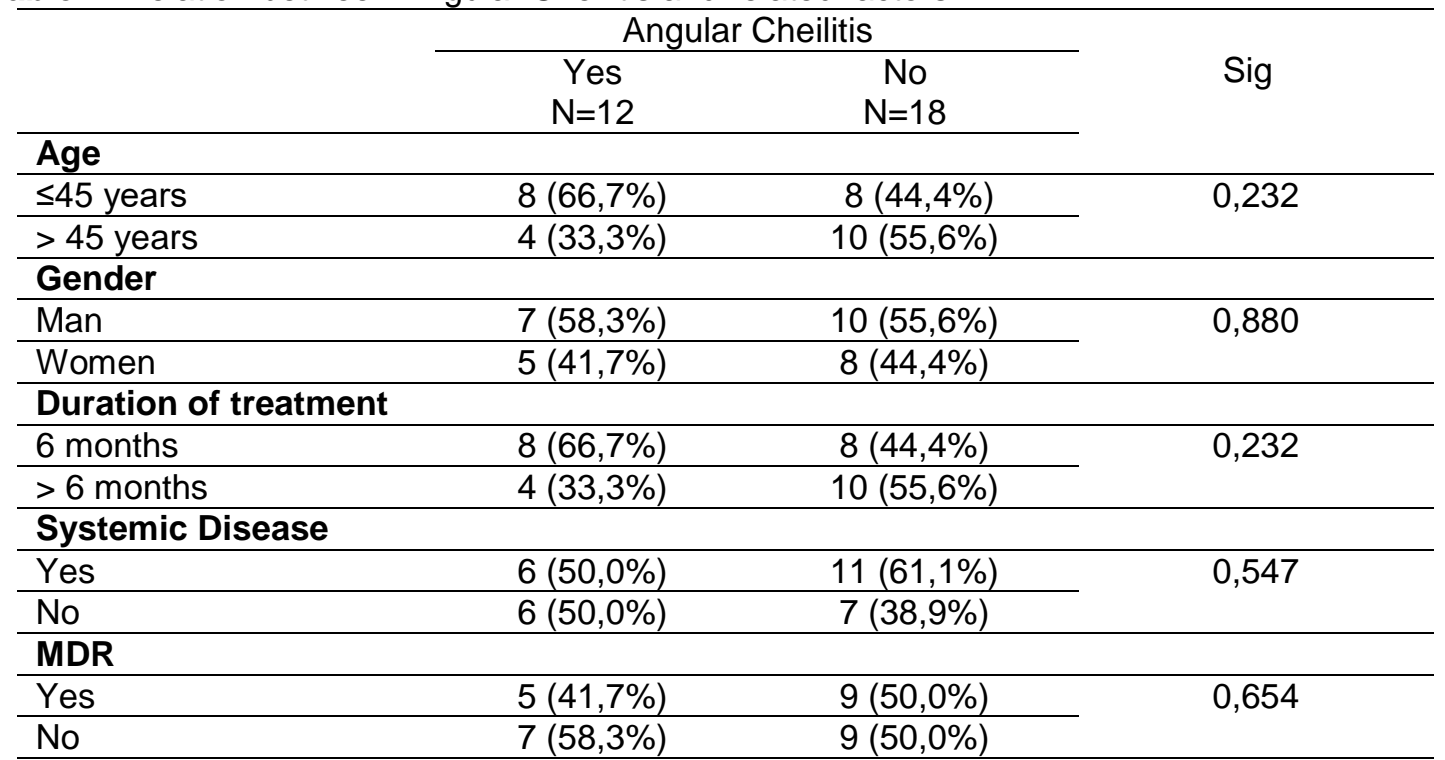

\section{DISCUSSION}

Relationship between Age and Clinical Manifestations of the Oral Cavity in Tuberculosis Patients
In this research, there was no significant relation between age with xerostomia, candidiasis, and angular cheilitis in oral Tuberculosis. 17 patients had xerostomia in their oral cavity and 13 
patients who did not have manifestations of xerostomia. 14 patients had candidiasis in their oral cavity and 16 patients who did not have candidiasis. 12 patients had angular cheilitis, and 18 patients did not have manifestations of angular cheilitis. The age group of TB patients in Indonesia of $75 \%$ is a productive age population of between 15-50 years $^{9}$. This is following this study showed more TB patients are $\leq 45$ years. Increasing productive activities and smoking habits at a young age in developing countries is one of the factors increasing the incidence of TB. Xerostomia can also be increased in elderly oral TB patients. In elderly xerostomia, patients are often associated with degeneration due to the ageing process. This causes a decline in salivary gland function where the loss of the parenchymal gland is replaced by fat tissue and connective tissue and the lining of intermediate duct cells that experience atrophy ${ }^{10}$.

Relationship between Gender and Clinical Manifestations of the Oral Cavity in Tuberculosis Patients

The results of this study also showed no significant correlation between sex with xerostomia, candidiasis, and angular cheilitis in oral Tuberculosis patients. The male group is the group with the most Tuberculosis in this study. This is also the same in the studies of Novita and Ismah (2017), the male sex group is the most suffering from TB (70\%) compared to women (30\%). Men have a risk condition than women ${ }^{11}$. Smoking and drinking alcohol habits in men can reduce the body's defence system. Men work and stay outside the home more than women. They have a high risk when working in a polluting enviroment ${ }^{12}$. Chronic effects of nicotine can cause changes in the composition of saliva. Smokers will also experience a decrease in the velocity of saliva due to atrophic asini cells in the salivary glands. When entering the elderly group, a woman will experience the ageing process. This natural process is called menopause, if a woman has entered the process, estrogen production will stop. This will affect the condition of the oral cavity so that it is vulnerable to dry mouth ${ }^{11,12}$.

Relationship between Duration of Treatment with Xerostomia in Tuberculosis Patients

In this study shows the significant correlation between the duration of treatment with xerostomia in Tuberculosis patients in RSUD Ulin Banjarmasin in January-March 2019. This can be related to the level of stress experienced by patients. Emotions can affect the autonomic nervous system, thus blocking the sympathetic nervous system from producing saliva. This is also related to the side effects of OAT, where one of the antituberculosis drugs, Isoniazid, has side effects such as xerostomia or dry mouth ${ }^{13,14}$.

Therapy for Tuberculosis is one of the longterm therapies. Prolonged treatment with a large amount of medication often makes TB sufferers complain like, dizziness, decreased appetite, anxiety, disturbed sleep patterns, and dry mouth. This situation is a symptom of stress. The study explains the longer TB treatment will be more severe than the stress level of TB patients ${ }^{14}$. The study shows there is a significant effect of stress and anxiety on saliva volume ${ }^{13}$. Some literature suggests that saliva volume is affected by stress and psychological conditions. Anxiety and depression can cause a decrease in salivary and xerostomia production. If someone has a chronic disease, including pulmonary TB, it will tend to experience depression because of decreased levels of monoamine in the brain. This decline in neurotransmitters in the brain can make pulmonary TB patients very susceptible to depression because 
neurotransmitters do not function according to their functions ${ }^{15,16}$.

Relationship Between Systemic Disease and Clinical Manifestations of the Oral Cavity in Tuberculosis Patients

In this study, there is a significant correlation between xerostomia and systemic disease. Systemic diseases that accompany respondents are Diabetes Mellitus and HIV/AIDS. DM patients increase the risk of 1.5 times the TB disease compared with respondents who do not have DM disease17. The longer a person has DM, the more complications in the oral cavity such as hyposalivation and xerostomia will appear. This is due to the relationship between blood glucose level levels of DM patients associated with the incidence of decreased salivary flow. Microvascular and neuropathic changes will affect the ability of the salivary gland to respond to neural or hormonal stimulation in TB patients ${ }^{18}$.

This study showed a significant correlation between candidiasis and systemic disease in Tuberculosis patients. Oral candidiasis is commonly found in TB patients with HIV/AIDS coinfection. Immunocompremais conditions generally accompany HIV/AIDS patients, making them vulnerable to oral infections. These conditions produce immune deficiency and disruption of cytokine production, which disrupts the phagocytic function of PMN and macrophages. The changes in oral epithelial cells cause changes in mucosal CD4 $\mathrm{T}$ cells and the reduction of Th1 cytokines in the saliva of chronic HIV patients. Antibiotics also can change the balance of commensal microorganisms in oral cavity and inhibit the growth of antagonistic commensal bacteria against Candida, thereby increasing the population of Candida ${ }^{19}$.
Relationship Between Patient Therapy MDR (MultiDrug Resistant) Status and Clinical Manifestations of the Oral Cavity in Tuberculosis Patients

In this study, there is no significant correlation between the treatment of Multi-Drug Resistant (MDR) patients with xerostomia, candidiasis, and angular cheilitis. Some drugs that are thought to cause side effects of nausea and vomiting are ethionamide, para-aminosalicylic acid, and pyrazinamide. The study showed that patient with TB treatment has a significant association with renal disorders. This situation is probably caused by long-term use of aminoglycoside drugs. The hearing disorder was found to be $59.6 \%$. Ototoxicity, as well as nephrotoxicity, have also been reported as side effects of aminoglycosides associated with large doses. Drug accumulation, duration of therapy, bacteremia, kidney or hepatic impairment, and also the use of MDR TB drugs with diuretics that have otocytosis effects are risk factors for ototoxicity ${ }^{20}$. This study shows that angular cheilitis did not correlate with all related factors. The previous study showed that angular cheilitis was the third-largest prevalence of oral mucosa disease of Gusti Hasan Aman Dental Hospital in Banjarmasin ${ }^{17}$. Based on Pemantauan Status Gizi (PSG) in 2016, South Kalimantan had $21,8 \%$ of malnutrition cases. The malnutrition condition caused by folic acid, iron and vitamin B12 deficiency which tend to increase the incidence of anaemia. Pathophysiology of anaemia which causes angular cheilitis due to a decrease in the mitochondria enzyme activity in cells, resulted in the disturbance of oxygen and nutrition transport ${ }^{21}$.

\section{CONCLUSION}

It can be concluded that clinical manifestations of oral Tuberculosis are xerostomia, candidiasis, and angular cheilitis. The duration of treatment and the systemic diseases are associated 
with xerostomia and candidiasis in the oral cavity of TB patients.

\section{ACKNOWLEDGMENT}

The authors would like to express their sincere gratitude to the Dentistry Faculty of University Lambung Mangkurat, Indonesia for supporting this research.

\section{CONFLICT OF INTEREST}

No conflict of interest is associated with this work.

\section{REFERENCES}

1. Jain A, Mittal S, Bansal R. Orofacial tuberculosis: Clinical manifestations, diagnosis, and management. J Fam Med Prim Care. 2015;4(3):335. DOI:10.4103/2249-4863.161312

2. Niţu FM, Olteanu M, Streba CT, et al. Tuberculosis and It's Particularities in Romania and Worldwide. Rom J Morphol Embryol. 2017;58(2):385-392.

3. WHO. Global Tuberculosis Report 2017: Leave No One behind - Unite to End TB.; 2017. DOI:10.1001/jama.2014.11450

4. Kemenkes RI. Hasil Utama Riskesdas 2018. 2018.

5. Reni, Wahyono TYM, Yulismar. Kejadian Efek Samping Obat Anti Tuberkulosis pada Pasien Tuberkulosis. J Respir Indo. 2016;36(4):222-230.

6. Priyandani $\mathrm{Y}, \mathrm{A}$ AF, Agung NAF, et al. Profil Problem Terapi Obat pada Pasien Tuberkulosis di Beberapa Puskesmas Surabaya. J Farm Komunitas. 2014;1(2):3035.

7. Saeed S, Hasan S. Tuberculosis: a Public Health Challenge: Brief Overview of Literature. Int Res J Pharm. 2016;7(January):1-4. DOI:10.7897/22308407.0711

8. Vučićević Boras V, Gabrić D, Smiljanić Tomičević L, et al. Tuberculosis of the Oral Cavity Misdiagnosed as Precancerous Lesion. Acta Stomatol Croat. 2017;51(4): 326-331. DOI:10.15644/asc51/4/7

9. Andayani S, Astuti Y. Prediksi Kejadian Penyakit Tuberkulosis Paru Berdasarkan Usia Di Kabupaten Ponorogo Tahun 20162020. Indones J Heal Sci. 2017;1(2):29. doi:10.24269/ijhs.v1i2.482
10. Marselia R, Wilson W, Pratiwi SE. Hubungan antara Lama Terapi terhadap Tingkat Gejala Depresi pada Pasien TB Paru di Unit Pengobatan Penyakit Paru-Paru Pontianak. J Cerebellum. 2017;3(3):831-841.

11. Ismah Z, Novita E. Studi Karakteristik Pasien Tuberkulosis Di Puskesmas Seberang Ulu 1 Palembang. Unnes J Public Heal. 2017;6(4): 218-224. doi:10.15294/ujph.v6i4.15219

12. Nurwanti N, Wahyono B. Hubungan Antara Faktor Penjamu (Host) dan Faktor Lingkungan (Environment) dengan Kejadian Tuberkulosis Paru Kambuh (Relaps) Di Puskesmas Se-Kota Semarang. Public Heal Perspect J. 2016;1(1):77-87.

13. Polimpung JAF, Pratiwi R. Pengaruh Stres, Depresi, dan Kecemasan Terhadap Volume Saliva pada Mahasiswa Preklinik Fakultas Kedokteran Gigi Universitas Hasanuddin. 2012:2-6.

14. Zahroh C, Subai'ah S. Hubungan Lama Pengobatan Tbc Dengan Tingkat Stres Penderita Tbc Di Puskesmas Tambelangan Kabupaten Sampang. J IIm Kesehat. 2016;9(2):138-145.

DOI:10.1017/CBO9781107415324.004

15. Martins N, Ferreira ICFR, Barros L, Silva S, Henriques M. Candidiasis: Predisposing Factors, Prevention, Diagnosis, and Alternative Treatment. Mycopathologia. 2014;177(5-6):223-240.

DOI:10.1007/s11046-014-9749-1

16. Astekar M, Bhatiya P, Sowmya G. Prevalence and Characterization Of Opportunistic Candidal Infections Among Patients With Pulmonary Tuberculosis. J Oral Maxillofac Pathol. 2016;20(2):183. DOI:10.4103/0973-029X.185913

17. Hatta I, Firdaus IWAK, Apriasari ML. The Prevalence of Oral Mucosa Disease of Gusti Hasan Aman Dental Hospital in Banjarmasin, South Kalimantan. Dentino J Kedokt Gigi. 2018;2(2):211-214.

18. Apriasari IH dan ML. Studi Deskripsi Laju Aliran Saliva pada Pasien Diabetes Melitus di RSUD Ulin Banjarmasin. J PDGI. 2014;63(1):8-13.

19. Lukisari C, Setyaningtyas D, Djamhari M. Penatalaksanaan kandidiasis oral disebabkan Candida tropicalis pada Anak dengan Gangguan Sistemik. J Dentomaxillofacial Sci. 2010;9(2):78. doi:10.15562/jdmfs.v9i2.236

20. Reviono, Kusnanto P, Eko V, Pakiding $\mathrm{H}$, Nurwidiasih D. Multidrug Resistant Tuberculosis (MDR-TB): Tinjauan Epidemiologi dan Faktor Risiko Efek Samping Obat Anti Tuberkulosis. Maj Kedokt Bandung. 2014;46(4): 189-196. doi:10.15395/mkb.v46n4.336 
21. Oktavia S, Mutahar R, Destriatania S. Analisis Faktor Risiko Kejadian Tb Paru Di Wilayah Kerja Puskesmas Kertapati Palembang Analysis Of Risk Factors For Pulmonary $\mathrm{Tb}$ Incidence. Jurnal IImu
Kesehatan Masyarakat sangat penting dan serius di seluruh dunia dan kedaruratan global (Global Emergenc). J ILMU Kesehat Masy. 2016;7(7):124-128 